\title{
Basic Income Grant as Innovative Social Policy against Poverty in Côte d'Ivoire
}

\author{
KAMALAN, A. E ${ }^{1}$. ; PRAO, Y. $S^{2}$.; AKA, B. $\mathrm{F}^{3}$. \\ \{eugenekamalan@gmail.com ${ }^{1}, \underline{\text { katythlinadja@gmail.com }}^{2}, \underline{\text { akbdia@yahoo.fr }}^{3}$ \} \\ Associate Professor, Department of Economics, Alassane Ouattara University, \\ Bouaké, Côte d'Ivoire, 28, BP 1694 Abidjan 28, Côte d'Ivoire', Tél 0022508727237; \\ Associate Professor, Department of Economics, Alassane Ouattara University ${ }^{2}$, \\ Professor, Department of Economics, Alassane Ouattara University ${ }^{3}$
}

\begin{abstract}
This paper implements a new way of innovative social policy with the basic income grant (BIG). We simulate an amount of FCFA12,000 (USD22.5) given monthly per individual to the whole population of Côte d'Ivoire and we analyze the impacts of this policy on individuals and groups. The simulations are performed using the Côte d'Ivoire's 2015 household survey data composed of 12,900 households. The results suggest that empowering the youth and women trough the unconditional basic income grant drastically reduces poverty.
\end{abstract}

Keywords: Basic income grant BIG; Social policy; Poverty; Welfare; Simulation

JEL Classification: H55; I32; I38; D31; C68

1. Introduction

A salient fact in African countries is the mismatch between the growing GDP and the stagnant well-being, growing poverty and inequality and declining welfare, particularly in a country as Côte d'Ivoire. This situation requires innovative public policy. In fact innovation appears as an imperative when things are worsening in our societies. When poverty and inequalities are growing in a country, politics are questioned to suggesting a solution. One of the most innovative public policy mechanisms proposed for poverty alleviation the last decade is the Basic Income Grant (BIG).

The Basic Income (BI) is defined by Philippe van Parijs as "an income paid by a political community to all its members on an individual basis, without means test or work requirement" [1]. It is also called a "Citizen's Income". In contrast to conventional social assistance subject to means tests, the BI is paid to everyone irrespective of income. This however does not mean the introduction of a BI would make the rich become richer, because the BI must be funded somehow, and the rich would contribute more (relative to their numbers, not necessarily to their incomes) to its funding than the relatively poor, not only if the funding were through a progressive income tax but also under a flat tax or even a regressive indirect tax.

All citizens are given a monthly stipend sufficiently high to provide them with a standard of living above the poverty line. This monthly income is universal and it is given automatically to all citizens regardless of their individual economic circumstances. Receiving the basic income does not depend upon performing any labour services or satisfying other conditions. In this way, basic income is like publicly-financed universal insurance. The unconditional and universal basic income takes the same stance about basic needs: as a matter of basic rights, no one should live in poverty.

In the case of Côte d'Ivoire, the government has set up an experiment basic income granted to selected households identified as the poorest of the poor, located in selected regions of the country. This policy is made 
by the Ministry of Employment and Social Protection and called: "Social Netting Project" "as an implementation of the National Strategy for Social Protection (SNPS).

The project is implemented in rural areas, because of the high poverty rate (58.6\% against $35.9 \%$ in urban areas), specifically in the Centre, the North and the West parts of the country, according to the standard of living of households in 2008 and 2015.

The project is to grant, free of charge, until 2020, a quarterly allowance of CFAF36,000 per trimester (i.e. CFAF12,000 per month) to 35,000 poor households, identified as the poorest of the poor. In addition to these cash transfers, the project provides for the selected households, accompanying measures to facilitate their social inclusion with awareness raising measures that enhance their quality of life and their empowerment by promoting productive inclusion.

In the theoretical views, one of the interesting issues raised in the researches of basic income concerns the distinction between distribution and redistribution. The expression: redistribution suggests that there is something called "distribution" which exists prior to political interventions and is then transformed by deliberate political action. This corresponds to the conventional rhetoric of economists and politicians: the income distribution generated by markets is the result of voluntary exchanges by freely acting individuals; this spontaneous distribution is then altered by acts of states which coercively take resources away from some people through taxes and transfer them to others. Redistribution reflects coercion; market-generated distribution reflects voluntary activity. This easily slides into the libertarian view that all redistribution is a violation of fundamental freedoms: taxation is theft; people have an absolute moral claim that whatever it is they can obtain from "voluntary exchange" in markets.

The real issue of the basic income is not about "Rethinking Redistribution" but it is a problem of "Redesigning Distribution." Income and wealth distributions are the result of the simultaneous, joint operation of voluntary choices of interacting individuals and authoritative rule-making and enforcement by states. The problem is to figure what combination of voluntary choice and authoritative allocation generates the most desirable outcomes, both in terms of efficiency considerations and moral concerns.

Historically, the issue of the state's positive role in shaping income distribution was at the centre of political debate in Europe and the United State in the 1970s. After the 2000's and the end of stabilization programs in developing countries in Sub Saharan Africa, governments and international institutions such us World Bank and International Monetary Fund have been engaged in the belief that, it is important to engage in rigorous analysis of alternative visions of institutional change [1].

In the following, section 2 of the paper presents the methodology and the data used in this study while section 3 presents the statistical results and policy experiments; finally section 4 gives a brief conclusion.

\section{Methodology and Data}

We present here the procedure to implement simulations on the micro impacts of the level of BIG, and the households' survey data used in this study.

In a first step we use expenditure vectors constructed from the household survey data (ENV2015 survey). We compute the income distribution indexes and then simulate the impact of the BIG on the income expenditure vector and then derive the distributional indexes which are compared to the base year.

Income distribution indexes

Prior to the study of poverty and inequality is the definition of welfare, or standard of living. The living standard for an individual is measured as his level of utility, obtained by maximization of his utility function for a given income and a price system. Given the difficulties for income measurement, surveys in developing countries rely on consumption criteria and expenditure per capita is therefore retained as welfare indicator.

\footnotetext{
${ }^{1}$ The Social Netting Project is made with the technical and financial support of the World Bank with a funding of 50 million USD.
} 
In Côte d'Ivoire the use of per capita consumption allows identifying several poverty lines. The permanent household survey in 1985 made by the National Institute of Statistics and the World Bank has estimated the poverty line at CFAF75000 and the poverty index (the population who live below the poverty line) was about $10 \%$.

The DSA ${ }^{2}$ survey in 1993 has estimated the poverty line at CFAF101,340 and 32.3\% of the population lived below this line. In 1995, poverty line was CFAF144,800 and 36.8\% of the population was below this relative poverty line. In 1998, poverty line was CFAF162,800 and poverty index was $33.6 \%$. In 2008, poverty line is CFAF241,145 and poverty index was $48.9 \%$. Recently in 2015, poverty line is CFAF269,075 and $46.3 \%$ of the population was below this poverty line. This approach arbitrarily determines the poverty line. A concept using the basic needs has been proposed by [9], [10], [11], [12] but the utilitarian view is still the main basic approach in welfare analysis.

\section{Measuring poverty}

The determination of poverty line is controversial when studying income distribution, because of its important political implications, [9] [10] [7]. Two approaches are frequently used to determine the poverty line. The first uses the notion of living standard Equivalent Distributed Equally (EDE), while the second combines the living standard and poverty line in a poverty gap.

In a previous study [2] the poverty line was constructed for Côte d'Ivoire based on the constant basic needs (CBN) approach by [8].

Using the ENV98 survey, he chooses a basket of 20 goods from the survey among the 37 items available. With the calories content of these goods (daily needs fixed at 2,400 calories) and their respective prices, he evaluated the food poverty line in Côte d'Ivoire at CFAF292,030.04 per year (US\$1.23 per day). Next, taking into account regional price index (RPI) for the five strata of the ENV98 survey, this poverty line has been evaluated to CFAF288,816.58 per year (US\$1.21 per day). As he used weights in the survey to compute the poverty line, the poverty line was thus measured per adult equivalent. In this study we use the poverty line calculated by National Institute of Statistics (NIS) which is evaluated at CFAF269,075 per year.

When the poverty line has been determined, several indexes help to characterize poverty (FGT index, Watts's index [13], and Clark, Hemming and Ulph (CHU) index) [5]. The FGT [6] is used in this study, as it is a more general index.

Given $\mathrm{y}_{\mathrm{i}}$, the income for individuals of a population, the FGT index is: $P(z ; \alpha)=\int_{0}^{1} \mathrm{~g}(\mathrm{p}, \mathrm{z})^{\alpha} d p$; where $\alpha \geq 0$ [7]. When $\alpha=0$, the FGT index indicates the proportion $P_{0}$ of poor person whose expenditure level is under the poverty line, and it measures the incidence of poverty. When $\alpha=1$, the index indicates the poverty gap index also known as depth or intensity of poverty i.e. the mean of the gap between poor people's living standard and the poverty line. When $\alpha=2$ the index is the poverty severity index, which is sensitive to the distribution of living standard among the poor.

The FGT indexes are decomposable, and this help looking at the contributions of different groups of households to global poverty. The contribution of each socio economic group to global poverty is given by:

$$
C_{j}=K_{j} P_{x_{j}} / P_{\alpha}
$$

Where $P_{x, j}$ is the poverty index for group $j, K_{j}$ the proportion of the population in group $j$. For inequality issues, the Atkinson and the Generalized Entropy inequality index are also decomposable in within group and between group inequalities [3]. In effect, the knowledge of groups' contributions in total index could be useful for formulating more precise economic policy towards most vulnerable groups.

Estimating areas income distribution

To better capture the impact of the simulations on areas, we will classify regions according to the strata of the survey by identifying the two self-governing districts and according to regions of the survey. A classification

\footnotetext{
${ }^{2}$ DSA (Priority Survey on the Social Dimensions of Structural Adjustment)
} 
based on the new thirty one regions in the country is also possible. Theses classifications will help to study poverty impacts at a much disaggregated level.

The data

We use the data from the ENV2015 household survey conducted in 2015 for Côte d'Ivoire which includes 12,900 households and 78,600 individuals organized in two (2) strata (self-governing district of Abidjan; selfgoverning district of Yamoussoukro) and thirty one regions.

\section{Statistical Results}

We keep the amount of the BIG equal to the allocation in test by the Ivorian government in selected regions and targeted individuals, i.e. CFAF12,000 per month (CFAF144,000 per year).

Taking a total population of 21 million in Côte d'Ivoire in 2016, giving this minimum to all population will lead to CFAF3,024 billion representing $15.9 \%$ of year 2016 GDP, which is possible ${ }^{3}$. For example for the France'economy the computed BIG in 2014 represents $15 \%$ of GDP [4].

Table2: Poverty alleviation with Basic Income Grant in Côte d'Ivoire

\begin{tabular}{llll}
\hline Estimate $^{4}$ & Base year & $\begin{array}{l}\text { After BIG } \\
\text { Simulation }\end{array}$ & $\begin{array}{l}\text { Variation } \\
\%\end{array}$ \\
\hline p0 & .5310 & .1472 & -.38 \\
p1 & .2070 & .0207 & -.19 \\
p2 & .1074 & .0043 & -.10 \\
\hline
\end{tabular}

Source: Authors' calculations

The results (Table 2 and Graph 1) show that after allocating a BIG to the whole population, global poverty drop from $53.1 \%$ to $14.7 \%$.

Graph 1: Density curve of poverty alleviation in Côte d'Ivoire

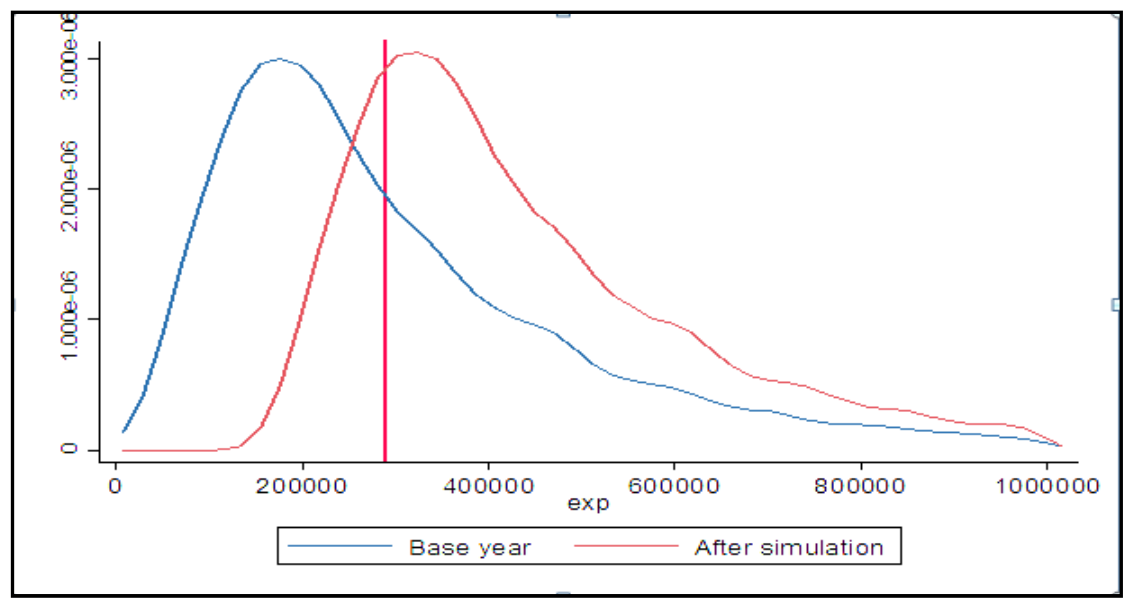

${ }^{3}$ Note that only the pro-poor spending in the Ivorian budget represents $9.1 \%$ of the 2016 GDP.

${ }^{4} \mathrm{P}_{0}$ : proportion of poor person whose expenditure level is under the poverty line and it measures the incidence of poverty.

$\mathrm{P}_{1}$ : the poverty gap, depth or intensity of poverty i.e. the mean of the gap between poor people's living standard and the poverty line.

$\mathrm{P}_{2}$ : the poverty severity index, which is sensitive to the distribution of living standard among the poor. 
Table 3: Poverty alleviation in the self-governing districts and all regions

\begin{tabular}{|c|c|c|c|c|}
\hline & strata & $\begin{array}{l}\text { Base } \\
\text { year }\end{array}$ & $\begin{array}{l}\text { After BIG } \\
\text { Simulation }\end{array}$ & $\begin{array}{c}\text { Variation } \\
\%\end{array}$ \\
\hline \multirow{3}{*}{ p0 } & self-governing district of Abidjan & .2496 & .0317 & -22 \\
\hline & self-governing district of Yamoussoukro & .4947 & .0954 & -40 \\
\hline & All (31) regions & .6343 & .1962 & -44 \\
\hline \multirow{3}{*}{ p1 } & self-governing district of Abidjan & .0693 & .0033 & -7 \\
\hline & self-governing district of Yamoussoukro & .1688 & .0101 & -16 \\
\hline & All (31) regions & .2621 & .0281 & -23 \\
\hline \multirow{3}{*}{ p2 } & self-governing district of Abidjan & .0290 & .0006 & -3 \\
\hline & self-governing district of Yamoussoukro & .0774 & .0017 & -8 \\
\hline & All (31) regions & .1400 & .0060 & -13 \\
\hline
\end{tabular}

Table 3 shows that in the self-governing district of Abidjan, poverty is reduced by $22 \%$ after simulation. This reduction is much more at the level of all regions (44\%) and in the self-governing district of Yamoussokro (40\%) from reference situation.

At a much more disaggregated level of the regions, the results (Table 4) indicate that poverty can be reduced by half. This is the case in regions as Bere (-53\%), Bounkani (-54\%), Folon (-51\%), Iffou (-58\%), Moronou ($52 \%)$, N'zi (-52\%) and Poro (-50\%).

Table 4: Poverty alleviation in the thirty one regions

\begin{tabular}{|c|c|c|c|c|c|c|c|c|c|}
\hline Regions & $\begin{array}{l}\text { Base } \\
\text { year }\end{array}$ & $\begin{array}{l}\text { After BIG } \\
\text { Simulation }\end{array}$ & $\begin{array}{c}\text { Variation } \\
\%\end{array}$ & $\begin{array}{l}\text { Base } \\
\text { year }\end{array}$ & $\begin{array}{c}\text { After BIG } \\
\text { Simulation }\end{array}$ & $\begin{array}{c}\text { Variation } \\
\%\end{array}$ & $\begin{array}{l}\text { Base } \\
\text { year }\end{array}$ & $\begin{array}{c}\text { After BIG } \\
\text { Simulation }\end{array}$ & $\begin{array}{c}\text { Variation } \\
\%\end{array}$ \\
\hline & \multicolumn{3}{|c|}{ P0 } & \multicolumn{3}{|c|}{$\mathrm{P} 1$} & \multicolumn{3}{|c|}{$\mathrm{P} 2$} \\
\hline agneby-tiassa & .5881 & .1769 & -41 & .2389 & .0238 & -22 & .1269 & .0048 & -12 \\
\hline bafing & .7530 & .3158 & -44 & .3569 & .0435 & -31 & .2043 & .0094 & -19 \\
\hline bagoue & .8040 & .4295 & -37 & .4135 & .0826 & -33 & .2693 & .0212 & -25 \\
\hline belier & .6949 & .2012 & -49 & .2760 & .0187 & -26 & .1363 & .0032 & -13 \\
\hline bere & .6915 & .1601 & -53 & .2694 & .0211 & -25 & .1338 & .0045 & -13 \\
\hline bounkani & .7559 & .2138 & -54 & .2899 & .0225 & -27 & .1456 & .0034 & -14 \\
\hline cavally & .5300 & .1821 & -35 & .2306 & .0308 & -20 & .1302 & .0071 & -12 \\
\hline folon & .7850 & .2756 & -51 & .3498 & .0339 & -32 & .1870 & .0061 & -18 \\
\hline gbeke & .5969 & .1585 & -44 & .2161 & .0218 & -19 & .1094 & .0041 & -11 \\
\hline gbokle & .5912 & .1842 & -41 & .2704 & .0332 & -24 & .1526 & .0075 & -15 \\
\hline goh & .5886 & .2620 & -33 & .2789 & .0523 & -23 & .1741 & .0136 & -16 \\
\hline gontougo & .5916 & .1496 & -44 & .2265 & .0157 & -21 & .1110 & .0026 & -11 \\
\hline grands-ponts & .5191 & .2284 & -29 & .2470 & .0324 & -21 & .1418 & .0063 & -14 \\
\hline guemon & .5387 & .1334 & -41 & .2124 & .0153 & -20 & .1038 & .0025 & -10 \\
\hline hambol & .6095 & .1433 & -47 & .2214 & .0182 & -20 & .1058 & .0042 & -10 \\
\hline haut-sassandra & .6028 & .1345 & -47 & .2197 & .0160 & -20 & .1060 & .0030 & -10 \\
\hline iffou & .7060 & .1301 & -58 & .2517 & .0140 & -24 & .1139 & .0021 & -11 \\
\hline indenie-djuablin & .5340 & .1361 & -40 & .2217 & .0179 & -20 & .1126 & .0030 & -11 \\
\hline kabadougou & .7785 & .3480 & -43 & .3987 & .0572 & -34 & .2411 & .0142 & -23 \\
\hline la me & .6023 & .2143 & -39 & .2672 & .0411 & -23 & .1569 & .0119 & -15 \\
\hline loh-djiboua & .5826 & .1352 & -45 & .2044 & .0180 & -19 & .0997 & .0034 & -10 \\
\hline marahoue & .5806 & .1752 & -41 & .2121 & .0180 & -19 & .1069 & .0026 & -10 \\
\hline moronou & .6384 & .1179 & -52 & .2298 & .0079 & -22 & .1037 & .0008 & -10 \\
\hline nawa & .4937 & .0732 & -42 & .1616 & .0085 & -15 & .0717 & .0014 & -7 \\
\hline n'zi & .6982 & .1772 & -52 & .2595 & .0148 & -24 & .1226 & .0017 & -12 \\
\hline
\end{tabular}




\begin{tabular}{l|lll|lll|lll|} 
poro & .6429 & .1453 & -50 & .2444 & .0191 & -23 & .1196 & .0035 & -12 \\
san-pedro & .4578 & .0987 & -36 & .1626 & .0140 & -15 & .0777 & .0026 & -8 \\
sud-comoe & .5135 & .0779 & -44 & .1909 & .0083 & -18 & .0882 & .0021 & -9 \\
tchologo & .7566 & .3449 & -41 & .3663 & .0597 & -31 & .2224 & .0143 & -21 \\
tonkpi & .7309 & .3322 & -40 & .3466 & .0500 & -30 & .2024 & .0103 & -19 \\
worodougou & .7072 & .2270 & -48 & .2896 & .0396 & -25 & .1618 & .0096 & -15 \\
\hline Mean All region & .6343 & .1962 & -44 & .2621 & .0281 & -23 & .1400 & .0060 & -13 \\
\hline
\end{tabular}

Source: Authors' calculations

Turning to the gender issue, the results (Table 5) indicate that after BIG simulation, poverty reduces more for female $(-39 \%)$ than male $(-38 \%)$, although it remain slightly higher for female $(15.15 \%)$ than male $(14.33 \%)$

Table 5: Poverty alleviation per gender with BIG

\begin{tabular}{clccc}
\hline \multirow{2}{*}{ Gender } & Base year & $\begin{array}{c}\text { After BIG } \\
\text { Simulation }\end{array}$ & Variation \% \\
\hline \multirow{2}{*}{ p0 } & male & .5216 & .1433 & -38 \\
& female & .5412 & .1515 & -39 \\
\cline { 2 - 5 } p1 & male & .2027 & .0205 & -18 \\
\cline { 3 - 5 } & female & .2116 & .0210 & -19 \\
\cline { 2 - 5 } p2 & male & .1052 & .0044 & -10 \\
& female & .1097 & .0044 & -11 \\
\hline \multicolumn{2}{c}{ Source: Authors' }
\end{tabular}

Source: Authors' calculations

Analysing poverty situation by age, the results (Table 6) indicate that after BIG simulation poverty reduces more for population over 40 years old $(-40 \%)$ than younger people $(-31 \%)$, but poverty remains higher for population over 40 years old $(16.75 \%)$ than younger people $(8.32 \%)$. This allocation could be very beneficial in reducing youth poverty in Cote d'Ivoire.

Table 6: Poverty alleviation per age with BIG

\begin{tabular}{|c|c|c|c|c|}
\hline & age & Base year & $\begin{array}{c}\text { After BIG } \\
\text { Simulation }\end{array}$ & Variation $\%$ \\
\hline \multirow{4}{*}{ p0 } & $<25$ & .3964 & .0832 & -31 \\
\hline & $25-30$ & .4600 & .1160 & -34 \\
\hline & $30-40$ & .5323 & .1423 & -39 \\
\hline & $\geq 40$ & .5671 & .1675 & -40 \\
\hline \multirow{4}{*}{$\mathrm{p} 1$} & $<25$ & .1345 & .0088 & -13 \\
\hline & $25-30$ & .1713 & .0152 & -16 \\
\hline & $30-40$ & .2072 & .0204 & -19 \\
\hline & $\geq 40$ & .2262 & .0240 & -20 \\
\hline \multirow{4}{*}{$\mathrm{p} 2$} & $<25$ & .0634 & .0016 & -6 \\
\hline & $25-30$ & .0852 & .0032 & -8 \\
\hline & $30-40$ & .1070 & .0043 & -10 \\
\hline & $\geq 40$ & .1195 & .0051 & -11 \\
\hline
\end{tabular}

Source: Authors' calculations 
Table 7: Poverty alleviation per gender and age with BIG

\begin{tabular}{|c|c|c|c|c|c|}
\hline & Gender & Age & Base year & $\begin{array}{c}\text { After BIG } \\
\text { Simulation }\end{array}$ & $\begin{array}{c}\text { Variation } \\
\%\end{array}$ \\
\hline \multirow{8}{*}{ p0 } & male & $<25$ & .3621 & .0813 & $-28 \%$ \\
\hline & male & $25-30$ & .4393 & .1166 & $-32 \%$ \\
\hline & male & $30-40$ & .5256 & .1371 & $-39 \%$ \\
\hline & male & $\geq 40$ & .5710 & .1662 & $-40 \%$ \\
\hline & female & $<25$ & .4550 & .0864 & $-37 \%$ \\
\hline & female & $25-30$ & .4859 & .1151 & $-37 \%$ \\
\hline & female & $30-40$ & .5392 & .1476 & $-39 \%$ \\
\hline & female & $\geq 40$ & .5632 & .1687 & $-39 \%$ \\
\hline \multirow{8}{*}{$\mathrm{p} 1$} & male & $<25$ & .1235 & .0092 & $-11 \%$ \\
\hline & male & $25-30$ & .1658 & .0158 & $-15 \%$ \\
\hline & male & $30-40$ & .2038 & .0199 & $-18 \%$ \\
\hline & male & $\geq 40$ & .2268 & .0243 & $-20 \%$ \\
\hline & female & $<25$ & .1532 & .0082 & $-14 \%$ \\
\hline & female & $25-30$ & .1782 & .0144 & $-16 \%$ \\
\hline & female & $30-40$ & .2107 & .0209 & $-19 \%$ \\
\hline & female & $\geq 40$ & .2255 & .0238 & $-20 \%$ \\
\hline \multirow{8}{*}{$\mathrm{p} 2$} & male & $<25$ & .0594 & .0018 & $-6 \%$ \\
\hline & male & $25-30$ & .0838 & .0033 & $-8 \%$ \\
\hline & male & $30-40$ & .1050 & .0042 & $-10 \%$ \\
\hline & male & $\geq 40$ & .1198 & .0052 & $-11 \%$ \\
\hline & female & $<25$ & .0703 & .0014 & $-7 \%$ \\
\hline & female & $25-30$ & .0869 & .0031 & $-8 \%$ \\
\hline & female & $30-40$ & .1091 & .0043 & $-10 \%$ \\
\hline & female & $\geq 40$ & .1192 & .0050 & $-11 \%$ \\
\hline
\end{tabular}

We can notice (Table 7) that young female ( $<25$ years) population poverty $(-37 \%)$ reduces more that young male ( $<25$ years) people $(-28 \%)$ but the poverty level for youth remain quite similar $(8.6 \%$ for female and $8.1 \%$ for male). This situation is symmetric for people over 40 years old. Male population over 40 years old poverty reduces more (-40\%) than female over 40 years old poverty $(-39 \%)$ but their poverty levels remain quite similar $(16.62 \%$ and $16.87 \%$ respectively) after BIG.

Other findings on poverty alleviation are related to regions of Côte d'Ivoire and disaggregated per gender and age. These findings are proposed in annexes.

\section{Conclusion}

The goal of this paper was to propose the universal basic income grant (BIG) as an innovative social policy for poverty alleviation in Côte d'Ivoire. We have simulated the amount of CFAF12000 (USD21.5) per month unconditionally given per individual to the whole population of the country. We analyzed the impacts of this policy on individuals and groups.

The simulations are performed using the Côte d'Ivoire's 2015 household survey data composed of 12,900 households and 78,600 individuals. The results suggest that empowering the youth and women trough the unconditional basic income grant drastically reduces poverty and regional end gender-based poverty. 
These results suggest that universal basic income grant can be an innovative and incentive mechanism to promote social and financial inclusion in Côte d'Ivoire. Future studies should address the impact of that mechanism on household's behaviour in Côte d'Ivoire in terms of consumption, saving and investment.

\section{References}

[1] Ackerman B., Alstott A. and Van Parij P. (2000). Basic Income: A Simple and Powerful Idea for the 21st Century, background paper for Basic Income European Network VIIIth International Congress Berlin, 6-7 October 200.

[2] Aka B.F. (2006), "Poverty Inequality and Welfare Effects of Trade Liberalisation: A CGE model for Côte d'Ivoire". African Economic Research Consortium Nairobi AERC Research Paper No. 16

[3] Atkinson A.B. (1987), “On the measurement of poverty”. Econometrica 55(4): 749-764.

[4] Bresson Y. (2014), "Le Revenu d'Existence. L'urgence de son instauration" Lettre de liaison 80 - AIRE Printemps 2014.

[5] Clark S. R. Hemming and D. Ulph.(1981), "On indices for measurement of poverty". Economic Journal 91(362):515-526.

[6] Foster J. J. Greer and E. Thorbecke.(1984). "A class of decomposable poverty measures".Econometrica, vol. 52(3):761-766

[7] Ravallion M. (1996), “Comparaison de la pauvreté". LSMS document de travail No. 122. Banque mondiale.

[8] Ravallion M. and B. Bidani.(1994), "How robust is a poverty profile?" World Bank Economic Review $8(1): 75-102$.

[9] Sen A.K. (1976), "Poverty: An ordinal approach to measurement”. Econometrica 44(2): 219-231.

[10] Sen A.K. (1981), "Poverty and Famines: An Essay on Entitlement and Deprivation". Oxford: Clarendon Press.

[11] Sen A.K. (1985), "A sociological approach to the measurement of poverty: Reply to Professor Townsend". Oxford Economic Paper, issue 37: 669-676.

[12] Sen A.K. (1987), “The Standard of Living”. Cambridge: Cambridge University Press.

[13] Watts H.W. (1968), “An economic definition of poverty”. In D.P. Moynihan ed. On Understanding Poverty. New York: Basic Books. 